\title{
Strengthening Indigenous Law to Make a Sustainable Development of the Coastal Area and Small Islands in Indonesia
}

\author{
Nurul Huda ${ }^{1, *}$, A.H. Asy'ari T. ${ }^{2}$, Yusuf Saefudin ${ }^{3}$, and Muhammad Bahrus Syakirin ${ }^{4}$ \\ ${ }^{1}$ Departement of Criminal Law, Faculty of Law, 51115, Universitas Pekalongan, Indonesia \\ ${ }^{2}$ Departement of Administrative Law, Faculty of Law, 51115, Universitas Pekalongan, Indonesia \\ ${ }^{3}$ Departement of Criminal Law, Faculty of Law, 51115, Universitas Pekalongan, Indonesia \\ ${ }^{4}$ Departement of Aquaculture, Faculty of Agriculture, 51115, Universitas Pekalongan, Indonesia
}

\begin{abstract}
Law no. 27 of 2007 on Management of Coastal Areas and Small Islands has the basis of consideration dimension of economic prosperity. The Act obtained Judicial Review to the Constitutional Court due to the rights of Coastal Waters Concession (HP-3). This article examines how the existence of indigenous and tribal peoples who have the right to be protected by the state constitution and how the legal analysis of the Judicial Review of the Act is reviewed. This research was conducted by a normative juridical method. The results show that indigenous and tribal peoples have not fully existed in the regulation and legal politics of Indonesia, particularly in the management of coastal areas and small islands. Judicial Review conducted to the Constitutional Court through Decision No. 3/ PUU-VIII / 2010 states that in certain articles in Law No. 27 of 2007 on the Management of Coastal Areas and Small Islands is contrary to the state constitution and has no binding power, which relates to Coastal Waters Rights which tend to be more liberal/capitalist because it can only be utilized by the owner of capital.
\end{abstract}

\section{Introduction and Literary Review}

Until 2020, there is targeted Marine, Coastal and Small Islands Conservation Area of $20,000,000$ ha in Indonesia. This target is to answer the mandate of Indonesia Republic Law No. 27 of 2007 as amended by Law No. 1 of 2014 [1].

The coast is a meeting area between land and sea. Towards land covering parts of the land, both dry and submerged in water, which are still affected by sea characteristics such as tides, sea breezes, and salt water permeation. Whereas to the sea includes parts of the sea which are still affected by natural processes that occur on lands such as sedimentation and freshwater flow or caused by human activities on land such as deforestation and pollution [2].

According to the terminology of Law No. 27 of 2007, Coastal Zone is a transitional area between terrestrial and marine ecosystems affected by changes in land and sea, while the

\footnotetext{
* Corresponding author: nurulhuda.unikal@gmail.com
} 
terminology for small islands is an island with an area smaller or equal to $2000 \mathrm{~km}^{2}$ (two thousand square kilometers) along with the unity of its ecosystem. In full, what is meant by coastal resources and small islands are biological resources, non-biological resources; artificial resources and environmental services. Biological resources include fish, coral reefs, sea grass beds, mangroves and other marine biotas. Non-living resources include pair, sea water, seabed minerals. Artificial resources include marine infrastructure related to marine and fisheries, and environmental services in the form of natural beauty, seabed surface underwater installations related to marine and fisheries and ocean wave energy found in coastal areas (article 1 point 3 and 4 Law No. 1 of 2014).

As we know that the birth of Law No. 27 of 2007 regarding Management of Coastal Areas and Small Islands which was ratified on July 17, 2007 on the basis of consideration of the Indonesian economic welfare dimensions, among others, stated that coastal areas and small islands have a high diversity of potential natural resource and very important for socio-economic, cultural, environmental, and development of the nation's sovereignty, therefore, must be managed in a sustainable and global-minded manner.

The purpose of the Law on the Management of Coastal and Small Islands Areas is principally namely: (1) Preparing regulations at the level of the law concerning the Management of Coastal Areas and Small Islands; (2) Building synergies and strengthening each other between Government agencies both at the central and regional levels; (3) Providing certainty and legal protection and improving the level of prosperity of coastal communities and small islands through the establishment of legislation.

Less than three years after Law No. 27 of 2007 was regulated, several provisions in the Law have been submitted to Judicial Review to the Constitutional Court by several nongovernmental organizations (NGOs) and individuals, among others by the NGO Alliance of People for Fisheries Justice (KIARA, Aliansi Rakyat untuk Keadilan Perikanan-Red.), Indonesian Human Rights Committee for Social Justice (IHCS), Center for Maritime Civil Development Studies (PK2PM), Agrarian Reform Consortium (KPA), Indonesian Peasant Union (SPI) and Bina Desa Sadajiwa Foundation.

This paper intends to highlight the issues related to "un-synchronization" between the articles in Law No. 27 of 2007 regarding Management of Coastal Areas and Small Islands with constitutional instruments especially relating to the rights of indigenous peoples who do have human rights that need to be protected by state constitution and how the discourses that develop in the Constitutional Court in the Judicial Review process submitted by several parties.

\section{Objective of the study}

This article examines how the existence of indigenous and tribal peoples who have the right to be protected by the state constitution of Indonesia. And how the legal analysis of the Judicial Review of Law No. 27 of 2007 regarding Management of Coastal Areas and Small Islands.

\section{Methodology}

The research method used in this paper was normative juridical, based on norms in legislation theory and doctrine related to Indigenous Law. The approach used in this study was the statute approach and the case approach. This research can also be categorized as prescriptive research, which is a study aimed at getting suggestions or recommendations regarding what should be done to overcome certain problems. 


\section{Discussion}

\subsection{Indigenous Law Rights in a Constitutional and Legal Perspective}

The existence or existence of indigenous peoples in the constitution is contained in article 18 of the 1945 Constitution which stated: the division of the Indonesian region over large and small regions, with the form of government structure stipulated by the Law, by considering and remembering the basic of deliberation in the state government system and, in the right of origin in special regions.

Explanation of article 18 stated on two things, namely: First, because the Indonesian state is an eenheidsstaat, Indonesia will not have a staat area in its environment. The Indonesian region will be divided into provincial and provincial regions will be divided into smaller areas. These areas are autonomous (streek and localerechtsgemeenschappen) or are merely administrative areas, all according to the rules that will be determined by law. In autonomous regions regional, the representative institution will be held because in the regions the government will be joined on the basic of deliberation. Second, in the territory of the Indonesian state, there are approximately 250 zelfbesturende landschappen and volksgemeenschappen, such as villages in Java and Bali, nagari in Minangkabau, hamlets and clans in Palembang and others. These regions have original arrangements, and therefore can be considered as special regions. The State of the Republic of Indonesia respects the position of these special regions and all state regulations concerning these regions will commemorate the rights of origin of the region.

Strengthening the existence of indigenous law communities can also be found in the amendments to Article 18B paragraph (1) and paragraph (2) of the 1945 Constitution after the second amendment in 2000 which among stated: (1) The State recognizes and respects regional government units that are specific or special nature regulated by law; and (2) The State recognizes and respects the unity of indigenous peoples and their traditional rights as long as they are alive and in accordance with the development of society and the principle of the unitary state of the Republic of Indonesia, which is regulated by the law.

The existence of indigenous law communities is reinforced by the birth of the Basic Agrarian Law (UUPA, Undang-Undang Pokok Agraria-Red.) which became the joint of national agrarian law based on the indigenous law on land, which is simple and guarantees legal certainty. In the UUPA, indigenous law occupies an important position because the law inspires all the substance of the UUPA, unfortunately this law is not implemented properly, many laws and regulations whose implementation is deviant and inconsistent, coupled with the paradigm of changing economic development that initially emphasized equity (socialism) becomes and changes towards growth (capitalism) so the UUPA starts to lose its socio-economic legitimacy and only remains the legal legitimacy [3]. The deterioration of the indigenous law community policy in the UUPA was exacerbated by the change of regime from the old order to the new order which put emphasis on economic development as a basic policy so that large-scale foreign investment was entered by legalizing Law No. 1 of 1967 regarding Investment.

The ebb and flow of Indigenous Law Society (MHA, Masyarakat Hukum Adat-Red.) recognition in Indonesia is increasingly felt with the birth of Law No. 6 of 2014 regarding Villages. Article 1 point 1 stated that villages are traditional villages and villages or are called by other names namely legal community units that have authorized territorial boundaries to regulate and administer government affairs, the interests of local communities based on community initiatives, traditional rights and / or rights which are recognized and respected in the government system of the Republic of Indonesia.

The practice that occurs related to MHA, its existence is not as stated in all the laws because the government's recognition of the MHA and its rights is "unclear" and also very 
rarely becomes a focus of attention and almost no recognition of it. The difficulty of recognizing the MHA is usually related to the demands of indigenous peoples for land and other natural resources [4].

Apart from the issue of the Village Law policy and the agrarian and investment issues, the existence of indigenous law communities was also "disturbed" by Law No. 1/Drt/1951. The existence of indigenous and tribal peoples in the law seen through their indigenous courts began not being recognized and abolished which continued after the Basic Law of Judicial Power was codified (Law No. 14 of 1970, later amended by Law No. 35 of 1999, amended again by Law No. 4 of 2004. The law was last amended by Law No. 48 of 2009), the existence of the Indigenous Court is no longer known. According to Article 1 paragraph (2) of Law/Drt/1951, it is stated that "at a time when the Minister of Justice will be gradually eliminated. All indigenous courts except the Religious Courts if the judiciary according to the living law is a separate are part of the indigenous court". Then an authentic explanation of the article mentioned the basic for the consideration of the elimination of indigenous justice because indigenous courts do not fulfill the requirements as court equipment as what is desired by UUDS and the people do not want [5].

Seeing the phenomenon of whether or not recognized of indigenous judiciary is in the discourse, it is also necessary to examine the future perspectives (ius constituendum), especially in the Draft of the Indigenous Peoples Protection drafted by the DPD and DPR which essentially provides recognition and protection of the rights of indigenous peoples for the Indonesian people [5].

\subsection{The Development of the Constitutional Thought in the Judicial Review of Law No. 27 of 2007 regarding Management of Coastal Areas and Small Islands}

Law No. 27/2007 concerning Management of Coastal Areas and Small Islands is considered to violate the rights of indigenous law communities. Because the regulation resulted in indigenous people having to compete with corporations to get rights to their ulayat territories [6].

If we read the Constitutional Court's frame of mind in relation to the objections of the petitioners for judicial review of Law No. 27 of 2007 seen in the Constitutional Court Decision No. 3/ PUU-VIII/2010, which basically states that article 1 number 18, Article 16, Article 17, Article 18, Article 19, Article 20, Article 21, Article 22, Article 23 paragraph (4) and paragraph (5), Article 50, Article 51, Article 60 paragraph (1), Article 71 and Article 75 , substantially the policy of Coastal Water Concession Rights (HP-3), further aggravates the revocation of the rights of coastal communities in accessing resources at sea level, bodies water or under the sea floor. There is no more space for coastal communities, especially fishermen, fish farmers, indigenous people, marine SME actors and fishermen workers to conduct economic activities in coastal areas.

Law No. 27 of 2007, in turn, leaves other issues, among others: First, this law always relates to adaptation to the global situation. It is not clear what the intended global context is. However, if examined more deeply, the global concept here is more directed at globalization; Second, privatization in a realm that must be controlled by the state and spatial issues; Third, protection of vulnerable groups in coastal villages; Fourth, the problem of poverty and state sovereignty on small islands; and Fifth, synchronize with other laws and regulations related to coastal area management [7]

Based on the above issues, various non-governmental organizations conducted Judicial Review of Law No. 27 of 2007 concerning Management of Coastal Areas and Small Islands. Material testing was submitted by nine non-governmental organizations actively advocating environmental and agricultural issues. They want the articles that rule the tenure 
rights to be revoked because they commercialize marine and coastal management. The law was also considered to overlap with licensing objects in the fields of forestry, mining, and tourism.

It was said by the Constitutional Court that the articles mentioned above were contrary to the 1945 Constitution of the Republic of Indonesia and did not have binding power. In its consideration, the Constitutional Court was of the opinion that the management of coastal areas and small islands were formulated / made with the aim of:

(1) Protect, conserve, rehabilitate, utilize and enrich coastal resources and small islands and their ecological systems in a sustainable manner;

(2) Creating harmony and synergy between the government and regional governments in the management of coastal resources and small islands, and

(3) Strengthen community participation and government institutions and encourage community initiatives in managing coastal and small island resources to achieve justice, balance, and sustainability [8].

Based on the objectives mentioned above, the Constitutional Court stated that the HP-3 policy set out in Law No. 27 of 2007 cannot be done. This is partly due to confusion or overlap between the HP-3 objects and licensing agents in the fields of forestry, mining, and tourism. The overlapping of such objects is:

(1) Between HP-3 and forestry licensing, which is about the use of mangrove forests, the fauna/flora found in coastal waters, and the use of environmental services in the mangrove forest area;

(2) Between HP-3 and mining permits, the use of sand as a resource in coastal areas and minerals in the sea;

(3) Between HP-3 and tourism licensing, namely the development of coastal tourism. Besides that, overlap also occurs with the object of regulation in the land sector [7].

According to the Constitutional Court, to avoid the transfer of responsibility for state control over the management of coastal waters and small islands to the private sector, the state can grant such management rights through the licensing mechanism. The granting of licenses to the private sector cannot be interpreted to reduce the authority of the state to make policies (beleid), make arrangements (regelendaad), administer (bestuursdaad), manage (beheersdaad) and carry out supervision (toezichthoudesndaad) for the greatest prosperity of the people.

In addition, it is still possible for the state to fully control and supervise all management of coastal waters and small islands. Through the licensing mechanism, the granting of management rights to the private sector does not constitute the granting of property rights that transfer the full state control to the private sector within a certain period of time.

Thus, coastal waters and small islands can still be managed in an integrated manner and build synergies in various sectorial plans, overlapping management, conflict of use and authority and providing legal certainty. That means giving HP-3 violates the principle of populist economic democracy because it will result in coastal waters and small islands becoming HP-3 territories controlled by large capital owners.

The concept of State Ownership Rights (HMN) which is taken into consideration by the Constitutional Court is not to mean that the state has but means that the state formulates policies, regulates, administers, manages and supervises. Thus, the meaning of controlling the state against the production branches that are important and affect the livelihood of many people, as well as for natural resources, does not deny the possibility of individuals or the private sector acting as long as the five roles of the state/government mentioned above are still fulfilled and throughout the government and the regional government does not or has not been able to implement it.

The issuance of Law No. 1 of 2014 concerning Amendments to Law No. 27 of 2007 concerning Management of Coastal Areas and Small Islands makes recognition and respect 
for indigenous peoples (MHA) with their traditional rights in accordance with the principles of the Republic of Indonesia, and recognizes also respects local and traditional communities living in coastal areas and small islands.

\section{Conclusion}

The indigenous peoples in Indonesia are existence, but there is no consistency in the regulation and political policies. There is a regulation that raises its existence such as the Basic Agrarian Law and the Village Law. There are also regulations that "interfere" with the existence of the MHA as in Law No. 1/Drt of 1951 and the Law on Judicial Power.

The results of the Judicial Review conducted by the Constitutional Court through Decision No. 3 / PUU-VIII / 2010 have stated that in certain articles in Law No. 27 of 2007 concerning Management of Coastal Areas and Small Islands is contrary to the state constitution and has no binding power, especially with regard to Coastal Water Concession Rights (HP-3) which are more likely to be liberal / capitalist.

\section{Reference}

1. A. James., A. Frederik W., L. Yoisye., M. Marvin M. Occasional Papers. 58, 37 (2017)

2. A. Soegiarto., Pedoman Umum Pengelolaan Wilayah Pesisir (National Oceanology Institute, Jakarta, 1976)

3. A. Sodiki, Urgensi Peneguhan UUPA dan Peraturan Pelaksanaannya untuk Mendukung Pelaksanaan Pembaruan Agraria dalam Pembentukan Kebijakan Reforma Agraria 2006-2007 (STPN Press, Yogyakarta, 2008)

4. M. A. Zain., Ahmad Siddiq., Pengakuan Atas Kedudukan dan Keberadaan Masyarakat Hukum Adat (MHA) Pasca Dibentuknya UU Nomor 6 tahun 2015 tentang Desa, J. Penelitian Hukum. 2, 64 (2015)

5. L. Mulyadi. Majalah Hukum. XXIX. 342, 28 (2014)

6. Tempo.co., Undang-undang Pesisir Dinilai Langgar Hak Masyarakat Adat, https://nasional.tempo.co/read/243666/undang-undang-pesisir-dinilai-langgar-hakmasyarakat-adat

7. Verdict Number 3/PUU-VIII/2010

8. T. C. Trinanda, J. Matra Pembaruan, 1, 75 (2017) 